\title{
Metabolic insufficiency underlies intratumoral cytotoxic T cell dysfunction
}

\author{
Tushar Gupta, Nicole E Scharping, Rebecca S Moreci, Greg M Delgoffe* \\ From 30th Annual Meeting and Associated Programs of the Society for Immunotherapy of Cancer (SITC 2015) \\ National Harbor, MD, USA. 4-8 November 2015
}

$\mathrm{T}$ cells have the remarkable ability to recognize and remove abnormal cells with precision, a feature that is very desirable for the treatment of cancer. However, while $\mathrm{T}$ cells specific for tumor antigens are primed and can infiltrate tumors, they are quickly rendered dysfunctional, through both cell intrinsic and cell extrinsic mechanisms. One way that tumors cripple T cell function is through the generation of an immunosuppressive microenvironment that is chronically inflamed, hypoxic, and nutrient poor. $\mathrm{T}$ cell activation and subsequent generation of effector function is bioenergetically demanding, requiring large amounts of metabolic intermediates to effectively proliferate, produce cytokines, and lyse target cells. We hypothesized that $\mathrm{T}$ cell dysfunction in cancer is due, in part, to metabolic insufficiency caused by chronic activation in metabolically dearth conditions. Using single-cell metabolic assays and extracellular flux analysis, we show that $\mathrm{CD} 8^{+}$cytotoxic $\mathrm{T}$ cells that infiltrate tumors demonstrate a progressive loss of mitochondrial function and mass, concomitant with upregulation of markers that correlate with $\mathrm{T}$ cell exhaustion. This mitochondrial dysfunction occurs independently of coinhibitory molecule signaling and specifically in the tumor microenvironment. This results in a failure to generate an adequate pool of ATP and in inability to effectively translate effector gene transcripts. This in stark contrast to $\mathrm{T}$ cells responding to an acute viral infection, where activated effector $\mathrm{T}$ cells demonstrate increased mitochondrial mass and ATP reserve. Further, artificial induction of mitochondrial dysfunction in $\mathrm{T}$ cells results in upregulation of coinhibitory molecules and an 'exhausted-like' phenotype, suggesting that metabolic insufficiency underlies the dysfunctional phenotype in cancer. Taken together, our data support a model in which tumor-infiltrating $\mathrm{T}$ cells have metabolic needs

University of Pittsburgh, Pittsburgh, PA, USA that cannot be met, resulting in failed effector function and tumor growth. Our studies also suggest that modulation or reprogramming of the altered metabolism of intratumoral $\mathrm{T}$ cells represents a potential strategy to reinvigorate dysfunctional $\mathrm{T}$ cells for the immunotherapeutic treatment of cancer.

Published: 4 November 2015

doi:10.1186/2051-1426-3-S2-P399

Cite this article as: Gupta et al:: Metabolic insufficiency underlies

intratumoral cytotoxic T cell dysfunction. Journal for ImmunoTherapy of Cancer 2015 3(Suppl 2):P399.

Submit your next manuscript to BioMed Central and take full advantage of:

- Convenient online submission

- Thorough peer review

- No space constraints or color figure charges

- Immediate publication on acceptance

- Inclusion in PubMed, CAS, Scopus and Google Scholar

- Research which is freely available for redistribution 